\title{
PRODUCTIVITY AND QUALITY OF COTTON FIBER IN DIFFERENT PLANTING SEASONS
}

\author{
PRODUTIVIDADE E QUALIDADE DE FIBRA DE ALGODÃO EM DIFERENTES \\ ÉPOCAS DE PLANTIO
}

\author{
Cynthia Pereira GUNDIM ${ }^{1}$; Daniel Bonifácio Oliveira CARDOSO ${ }^{2 *}$; \\ Melissa Cristina de Carvalho MIRANDA ${ }^{3}$; Victor Martins da SILVEIRA ${ }^{2}$; \\ Luiza Amaral MEDEIROS ${ }^{2}$; Larissa Barbosa de SOUSA ${ }^{2}$ \\ 1. Cia da Terra, Uberlândia, Minas Gerais, Brazil; 2. Universidade Federal de Uberlândia, Instituto de Ciências Agrárias, Uberlândia, \\ Minas Gerais, Brazil. danieludia13@hotmail.com; 3. Universidade de São Paulo, Escola Superior de Agricultura Luiz de Queiroz, \\ Departamento de Genética e Melhoramento de Plantas, Piracicaba, São Paulo, Brazil.
}

\begin{abstract}
Cotton is one of the main agricultural products produced in Brazil. With such a high demand in the market, it is necessary that the cotton cultivars present high productivity and fiber quality. In order to favor the expression of the potential of the genotypes, the cultivation must occur in climatic conditions that provide good development of the plants, being the sowing time a primordial factor for the good performance of the cotton plant. In order to establish an ideal sowing season for different cotton genotypes, the present study aimed to evaluate the best sowing season of cotton genotypes for the environment of Uberlândia (Minas Gerais State), aiming at productivity and fiber quality. The experiment was carried out in field conditions, in the 2016/2017 harvest in the experimental area located at Fazenda Capim Branco, in the city of Uberlândia, Minas Gerais State. A randomized complete block design (DBC) with four replications in a $4 \times 7$ factorial scheme was used: 4/12 sowing dates: 05/12, 19/12, 30/12, 13/01 and 7 genotypes. 5 strains of the breeding program of the Federal University of Uberlândia (UFU) and 2 commercial cultivars. The evaluated characteristics were: seed cotton yield, feather yield, micronaire index, maturity index, fiber length, uniformity of length, short fibers, resistance and elongation. It was concluded that the best sowing season for a high productivity was the one performed on $12 / 05 / 16$, with emphasis on the UFUJP-Z genotype. For fiber quality, UFUJP-C showed the best results at the 12/19/16 sowing season.
\end{abstract}

KEYWORDS: Gossypium hirsutum. Micronaire. Temporal conditions.

\section{INTRODUCTION}

The cotton (Gossypium hirsutum L.) has great socioeconomic importance worldwide, given its influence in several sectors of society, besides the wide use of its by-products (CHITARRA, 2014). In economic terms, the crop is considered as "trina", for producing fiber as the main product, which currently dresses almost half of humanity, as well as oil for human consumption and energy production through biodiesel (BELTRÃO; AZEVEDO, 2008; HEQUET, 2014).

In Brazil, the farming is of great importance in the agricultural trade balance. Cotton is cultivated in all regions, with emphasis on the Cerrado biome (COMPANHIA NACIONAL DE ABASTECIMENTO, 2018). Due to the great extent of the Cerrado, cotton cultivars are exposed to a high diversity of environmental conditions, such as temperature, precipitation and luminosity, the agricultural zoning being an indication of ideal growing conditions.
In the definition, the agricultural zoning takes into account the environmental conditions favorable to the good development of the crop, highlighting the sowing season. The correct season should provide higher productivity and better fiber quality, in order to avoid possible adverse climatic phenomena, such as droughts, low temperatures and rainfall in the harvest (AMORIM NETO et al., 1997.

In Minas Gerais State, cotton is traditionally sown in the months of November to December and harvested between June and July (FERREIRA et al., 2015), as the crop finds climatic conditions favorable to its development, such as temperatures ranging from $20^{\circ} \mathrm{C}$ to $30^{\circ} \mathrm{C}$ in the summer and precipitations that vary between 700 and $1500 \mathrm{~mm}$, ideal to complete its cycle (BELTRÃO et al., 2015).

The reproductive development of cotton is the most sensitive phase to thermal stress, being that high temperatures can reduce the cycle's duration, inhibiting the development of structures important for fertilization, which leads directly to losses in seed production, yield and quality of fibers. At low 
temperatures, apical bud death can occur, malformation of radicles, in addition to delayed development and flowering of the crop. Hydric stress can result in the closure of the stomata, limiting the evaporative cooling of the leaf, which induces a thermal stress in the cotton, even in optimal conditions of the environment's temperature (ROSOLEM et al., 2014).

When the early planting is done, the cotton crop can be submitted to low temperatures and lack of humidity, which damages the germination and its initial development. Besides, the harvest can coincide with the rainy seasons, causing damages to the seeds and the fiber quality (BELTRÃO, 1997 LACA-BUENDÍA et al., 2005). The late planting is detrimental, as it decreases production, due to the greater occurrence of pests and diseases, besides causing the delay in the opening of the bolls by the temperature drop (LACA-BUENDÍA et al., 2005; ECHER, 2014).

Changes in the environment modify the genotypes expression, especially when working with characteristics determined by many genes, such as yield, production components and fiber quality, which consists the main market requirements and focus of improvement programs (BONIFÁCIO, et al., 2015).

Based on what has been mentioned above, this study had as objective to evaluate the best sowing season of different cotton genotypes in the region of Uberlândia, Minas Gerais State, aiming better productivity and fiber quality.

\section{CONTENTS}

Table 1. Mean of maximum and minimum temperature, sum of precipitation of each sowing season and degrees-day accumulated in the cotton cycle. Uberlândia, Minas Gerais State, Brazil, 2016/2017.

\begin{tabular}{ccccc}
\hline Sowing Season & $\begin{array}{c}\text { Maximum } \\
\text { Temperature }\left({ }^{\circ} \mathrm{C}\right)\end{array}$ & $\begin{array}{c}\text { Minimum } \\
\text { Temperature }\left({ }^{\circ} \mathrm{C}\right)\end{array}$ & $\sum$ Rain $(\mathrm{mm})$ & Degree-day \\
\hline E1 $(12 / 05 / 16)$ & 28.70 & 18.36 & 956.1 & 1932.55 \\
E2 $(12 / 19 / 16)$ & 28.55 & 17.98 & 764.4 & 1677.6 \\
E3 $(12 / 30 / 16)$ & 28.26 & 17.60 & 701.4 & 1616.4 \\
E4 $(01 / 13 / 17)$ & 27.77 & 17.04 & 679.7 & 1521.85 \\
\hline
\end{tabular}

The agronomic characteristics evaluated were the productivity of the cottonseed and lint yield. The productivity of cottonseed is determined by the collection and weighing of all the opened cotton bolls of the useful area of each plot $\left(\mathrm{kg} \mathrm{ha}^{-1}\right)$. The lint yield, in other hand, was determined by obtaining the ratio between the lint and the cottonseed mass of each useful plot.

The fiber quality characteristics evaluated were micronaire index, maturity index, fiber length,
The experiment was conducted in the experimental area located at Capim Branco Farm ( $18^{\circ} 52$ 'S, $48^{\circ} 20^{\prime} \mathrm{W}$ and $805 \mathrm{~m}$ altitude), from the Federal University of Uberlândia, in the city of Uberlândia, State of Minas Gerais, on a dystrophic Dark Red Latosol (EMBRAPA, 2013).

For the experiment, the complete randomized block delineation (DBC) with three repetitions was adopted. The experimental portion was composed of three rows of five meters in length, spaced one meter apart and with a density of eight plants per linear meter. The center line was considered as useful area, disregarding $0.50 \mathrm{~m}$ from each end.

Seven genotypes of cotton were evaluated, five strains being from the Federal University of Uberlândia (UFUJP-A, UFUJP-C, UFUJP-P, UFUJP-S and UFUJP-Z) and two commercials: Delta Pine 555 (DP 555) and Fibermax 966 (FM 966), in four sowing dates $12 / 05 / 16,12 / 19 / 16$, 12/30/16, 01/13/17 (E1, E2, E3, E4, respectively).

The meteorological conditions of temperature $\left({ }^{\circ} \mathrm{C}\right)$ and precipitation $(\mathrm{mm})$ that occurred during the conduction of the experiment were collected through a Davis Vantage Pro2 automatic meteorological station. Table 1 shows the averages of maximum and minimum temperature, the sum of the precipitations in each sowing season, as well as the values of thermal accumulation, degree-days accumulated in the cotton cycle, calculated according to the function.

Legee-day $=\left[\frac{\text { Maximum Ternp-Minimum Temp. })}{2}\right]$-Basal Temperature uniformity of length, short fiber index, fiber resistance and elongation, analyzed by the HVI (High Volume Instruments) apparatus at Minas Cotton (Central de Classificação de Fibra), in Uberlândia - Minas Gerais State.

The data were submitted to analysis variance (F-Test) and when significant differences were detected, Scott-Knott's test (1974) were performed, both 0.05 of significance using the 
Productivity and quality...

Computational Program in Genetics and Statistics (GENES) (CRUZ, 2013).

Interaction between genotypes and sowing seasons for the characteristics of cottonseed, micronaire (MIC) and maturity (MAT) was observed, evidencing that the different sowing seasons directly interfere with the phenotypic expressions of the genotypes. The characteristics lint yield, UHML, UI, STR and ELG, in turn, presented genetic variability.

The sowing seasons interfered in the expression of productivity and performance, which shows that depending on the sowing date, the performance will oscillate due to biotic and abiotic factors. Each cultivar presents thermal needs, denominated degrees-days to perform its cycle, being necessary sowing at the ideal time, latitude and altitude for this variety, otherwise losses of
GUNDIM, C. P. et al.

cotton productivity may occur (BELTRÃO et al., 2015). On the other hand, when analyzing only the technological characteristics of the fiber, the environmental factor exerted little influence, except for the variable ELG.

The genotypes showed high performance for cottonseed yield when submitted to the first sowing season $(12 / 5 / 16)$. This fact can be explained due to the occurrence of maximum and minimum temperature within the considered ideal for the crop, along with accumulated precipitation above the required one. The average yield of cottonseed was $1447.69 \mathrm{~kg} \mathrm{ha}^{-1}$, highlighting the genotype UFUJP$\mathrm{Z}$ with $3116.52 \mathrm{~kg} \mathrm{ha}^{-1}$ (Table 2). The genotypes FM-966 (1214.80 $\mathrm{kg} \mathrm{ha}^{-1}$ ) and UFUJP-S (1191.64 $\mathrm{kg} \mathrm{ha}{ }^{-1}$ ) obtained lower performances than the other genotypes, being little responsive to the environment's conditions.

Table 2. Cottonseed productivity $\left(\mathrm{kg} \mathrm{ha}^{-1}\right)$ in cotton genotypes according to sowing seasons. Uberlândia, Minas Gerais State, Brazil, 2016/2017.

\begin{tabular}{cccccc}
\hline \multirow{2}{*}{ Genotype } & \multicolumn{5}{c}{ Sowing season } \\
\cline { 2 - 5 } & $12 / 05 / 2016$ & $12 / 19 / 16$ & $12 / 30 / 16$ & $01 / 13 / 17$ & Mean \\
\cline { 2 - 5 } DP-555 & $2672.59 \mathrm{Aa}$ & $1329.04 \mathrm{Ba}$ & $1426.41 \mathrm{Ba}$ & $736.90 \mathrm{Ba}$ & 1541.23 \\
FM-966 & $1800.57 \mathrm{Ab}$ & $1215.73 \mathrm{Aa}$ & $1237.89 \mathrm{Aa}$ & $605.02 \mathrm{Ba}$ & 1214.8 \\
UFUJP-A & $2372.19 \mathrm{Aa}$ & $1331.02 \mathrm{Ba}$ & $1436.24 \mathrm{Ba}$ & $616.15 \mathrm{Ca}$ & 1438.9 \\
UFUJP-C & $2530.93 \mathrm{Aa}$ & $1348.85 \mathrm{Ba}$ & $1224.58 \mathrm{Ba}$ & $661.82 \mathrm{Ba}$ & 1441.54 \\
UFUJP-P & $2934.65 \mathrm{Aa}$ & $1408.33 \mathrm{Ba}$ & $1546.67 \mathrm{Ba}$ & $684.39 \mathrm{Ca}$ & 1643.51 \\
UFUJP-S & $1250.23 \mathrm{Aa}$ & $1408.33 \mathrm{Aa}$ & $1384.74 \mathrm{Aa}$ & $723.27 \mathrm{Ba}$ & 1191.64 \\
UFUJP-Z & $3116.52 \mathrm{Aa}$ & $1408.33 \mathrm{Ba}$ & $1371.84 \mathrm{Ba}$ & $644.04 \mathrm{Ca}$ & 1635.18
\end{tabular}

${ }^{1}$ Averages followed by distinct letters, upper case in the row and lowercase in the column, belonging to distinct groups, by the ScottKnott test at 0.05 significance.

Cotton cultivation is extremely influenced by the accumulation of degrees-days to complete its cycle fully, establishing a cultivar and production environment connection (ECHER, 2014). Thus, once the greatest accumulation of degree-days was recorded for season 1, and the gradual decrease occurred with subsequent seasons, there was a direct reduction in productivity and development of the genotypes in seasons 2, 3 and 4 .

It should be noted that in season 2 $(12 / 19 / 16)$, there was a reduction in the productive potential of all genotypes, except for UFUJP-S, which, even in adverse conditions, obtained good performance, presenting a $30.6 \%$ higher in respect to the average obtained in season 1 , and it can be inferred that the genotype is promising for these unfavorable abiotic conditions. In season 2 , it was observed that there was a shortage of rain in the filling stage of the bolls, one of the most sensitive phases to the water deficit, since there is an increase in the demand to meet the physiological needs of the plant.

Coutinho et al. (2015), observed the lowest weight of 100 seeds due to the low precipitation during the beginning of the reproductive stage, corroborating with the present work. Rosolem (2001) found that in this phase, the increase of the leaf area contributes to the increase of the water requirement of the plant, so that the plant can maintain its physiological activities. 
Productivity and quality...

Rosolem (2014) studying the evapotranspiration of the cotton, concludes that at the beginning of the cycle until the appearance of the first bud, the plant presents low transpiration, requiring less than $1.0 \mathrm{~mm}$ per day. Up to the opening of the first flower this value increases to 4.0 $\mathrm{mm}$, and from the opening of the first flower to the opening of the first boll, perspiration can reach 8.0 $\mathrm{mm}$ per day. Soon after the opening of the first boll the water requirement drops. Almeida et al. (2017) evaluating the water deficit in the phenological stages, concluded that when there is a deficit during the appearance of the first flower bud until the appearance of the first flower, cotton production is significantly compromised.

In general, it is verified that the later the planting of the cotton takes place, the lower the yields obtained by the genotypes are. Similar results were found in studies by Ferreira et al. (2015), which analyzed sowing in the second fortnight of January and the first fortnight of February of a three-year harvest, and found that late sowing reduces lint yield by $25 \%, 17 \%$ and $41 \%$ in the years studied. Carvalho et al. (2011) also verified higher productivity of cotton seed when cotton was sown at the end of December in contrast to sowings in January and February.
GUNDIM, C. P. et al.

According to Gabriel et al. (1997), late sowing provided a greater attack of cotton boll weevil, which affects the opening of buds, besides providing a loss of strength on the upper part of the plant due to the occurrence of low temperatures, which corroborates with Laca-Buendía (2005), who evaluated planting seasons for early genotypes of herbaceous cotton in the city of Uberaba - Minas Gerais State and concluded that late plantings, as of December 17 , reduced productivity by $49 \%$, concomitantly reducing the plant's height and fiber yield.

However, sowings carried out before the recommended season for the region also culminate in large losses, due to the final phase of the crop and harvest may coincide with rainy periods, implying a humid microclimate and favoring the rotting of the bolls in different stages, in order to compromise the production and quality of the fiber. In addition, due to the cloudy weather, photosynthesis is reduced due to lack of light, also damaging the quality of the fiber (ROSOLEM, ECHER, 2015).

For lint yield, only genotypes DP-555, FM966 and UFUJP-A varied in relation to sowing seasons, but according to Mahmood-Ul-Hassan et al. (2003), sowing seasons directly influence cotton yield, as they interfere with the weight of bolls and the formation of bolls per plant (Table 3 ).

Table 3. Lint yield in cotton (\%) in cotton genotypes according to sowing seasons. Uberlândia, Minas Gerais State, Brazil, 2016/2017.

\begin{tabular}{|c|c|c|c|c|c|}
\hline \multirow{2}{*}{ Genotype } & \multicolumn{4}{|c|}{ Sowing season } & \multirow{2}{*}{ Mean } \\
\hline & $12 / 05 / 2016$ & $12 / 19 / 16$ & $12 / 30 / 16$ & $01 / 13 / 17$ & \\
\hline DP-555 & $39.55 \mathrm{Aa}$ & $36.73 \mathrm{Ba}$ & 39.32Aa & $40.75 \mathrm{Aa}$ & 39.08 \\
\hline FM-966 & $36.80 \mathrm{Ba}$ & $35.78 \mathrm{Ba}$ & $38.40 \mathrm{Aa}$ & $39.02 \mathrm{Ab}$ & 37.50 \\
\hline UFUJP-A & $37.37 \mathrm{Ba}$ & $35.37 \mathrm{Ba}$ & $37.88 \mathrm{Ba}$ & $40.75 \mathrm{Aa}$ & 37.84 \\
\hline UFUJP-C & $37.34 \mathrm{Aa}$ & 35.07Aa & 36.66Aa & $38.12 \mathrm{Ab}$ & 36.80 \\
\hline UFUJP-P & 36.32Aa & $35.05 \mathrm{Aa}$ & $37.18 \mathrm{Aa}$ & $36.75 \mathrm{Ab}$ & 37.32 \\
\hline UFUJP-S & $36.33 \mathrm{Aa}$ & $34.68 \mathrm{Aa}$ & $36.13 \mathrm{Aa}$ & $37.89 \mathrm{Ab}$ & 36.25 \\
\hline UFUJP-Z & $37.55 \mathrm{Aa}$ & $35.68 \mathrm{Aa}$ & $38.22 \mathrm{Aa}$ & $38.37 \mathrm{Ab}$ & 37.45 \\
\hline
\end{tabular}

${ }^{1}$ Averages followed by distinct letters, upper case in the row and lowercase in the column, belonging to distinct groups, by the ScottKnott test at 0.05 significance.

The characteristics of lint yield and performance are correlated, since the first is the ratio between feather and cottonseed productivity. These are quantitative traits, ruled by many genes, and thus greatly influenced by environmental factors. It is observed that the DP 555 genotype presented a below-average productivity of the best genotypes but compensated for the lower productivity with high fiber yield $(39.09 \%)$. On the other hand, the cultivars UFUJP-P $(36.32 \%)$ and UFUJP-Z (37.46\%) presented high productivity, but in contrast, they did not express high fiber yield values. 
Coutinho et al. (2015) evaluating commercial cultivars in the semi-arid region of Minas Gerais State, found an average yield of $39.32 \%$, higher than the genotypes evaluated in this study, which was $37.33 \%$, but considered satisfactory yield results, as long as allied to high performances.

For the UHML, UI and STR characteristics, the sowing times did not interfere in the phenotypic expression, which may allow greater success in the selection of superior genotypes, since the phenotype represents the genetic potential of the cultivar, suffering little interference from the environment (Table 4). The genotypes met the parameters required by the textile industry with micronaire index ranging from 3.5 to 4.3 , and fiber maturity above 0.8 (EMBRAPA, 2002).

According to Miranda (2019), the quality characteristics of the fiber, although quantitative, are less influenced by the environment in relation to the agronomic variables, as proven by its limits for the variation coefficients lower and with consequent higher precisions. Penna (2005) also proposes that, in general, the influence of the environment is high for productivity, average for the production components and low for the physical characteristics of the fiber.

Table 4. Micronaire averages and fiber maturity of cotton genotypes as a function of sowing season. Uberlândia, Minas Gerais State, Brazil, 2016/2017.

\begin{tabular}{|c|c|c|c|c|c|c|c|c|}
\hline \multirow{3}{*}{ Genotype } & \multicolumn{8}{|c|}{ Sowing season } \\
\hline & \multicolumn{2}{|c|}{$05 / 12 / 16$} & \multicolumn{2}{|c|}{$19 / 12 / 16$} & \multicolumn{2}{|c|}{$30 / 12 / 16$} & \multicolumn{2}{|c|}{$13 / 01 / 17$} \\
\hline & MIC & MAT & MIC & MAT & MIC & MAT & MIC & MAT \\
\hline DP-555 & $4.28 \mathrm{Aa}$ & $0.86 \mathrm{Aa}$ & $3.19 \mathrm{Bb}$ & $0.83 \mathrm{Bb}$ & $3.72 \mathrm{Aa}$ & $0.83 \mathrm{Bb}$ & 3.99Aa & $0.84 \mathrm{Ba}$ \\
\hline FM-966 & 3.94Aa & $0.85 \mathrm{Aa}$ & $3.23 \mathrm{Ab}$ & $0.83 \mathrm{Bb}$ & $3.80 \mathrm{Aa}$ & $0.84 \mathrm{Aa}$ & $3.56 \mathrm{Aa}$ & $0.83 \mathrm{Ba}$ \\
\hline UFUJP-A & $3.76 \mathrm{Aa}$ & $0.84 \mathrm{Ab}$ & $3.24 \mathrm{Bb}$ & $0.83 \mathrm{Ab}$ & 4.09Aa & $0.85 \mathrm{Aa}$ & $4.00 \mathrm{Aa}$ & $0.84 \mathrm{Aa}$ \\
\hline UFUJP-C & $3.64 \mathrm{Aa}$ & $0.84 \mathrm{Ab}$ & $3.76 \mathrm{Aa}$ & $0.84 \mathrm{Aa}$ & $3.84 \mathrm{Aa}$ & $0.85 \mathrm{Aa}$ & 3.29Aa & $0.83 \mathrm{Ba}$ \\
\hline UFUJP-P & $3.41 \mathrm{Ab}$ & $0.84 \mathrm{Ab}$ & $3.93 \mathrm{Aa}$ & $0.84 \mathrm{Aa}$ & $3.63 \mathrm{Aa}$ & $0.83 \mathrm{Ab}$ & $3.76 \mathrm{Aa}$ & $0.84 \mathrm{Aa}$ \\
\hline UFUJP-S & $3.41 \mathrm{Bb}$ & $0.84 \mathrm{Ab}$ & $4.43 \mathrm{Aa}$ & $0.85 \mathrm{Aa}$ & $3.86 \mathrm{Ba}$ & $0.84 \mathrm{Aa}$ & $3.77 \mathrm{Ba}$ & $0.84 \mathrm{Aa}$ \\
\hline UFUJP-Z & $3.01 \mathrm{Bb}$ & $0.83 \mathrm{Ab}$ & 3.99Aa & $0.84 \mathrm{Aa}$ & $3.24 \mathrm{Ba}$ & $0.83 \mathrm{Ab}$ & $3.77 \mathrm{Aa}$ & $0.84 \mathrm{Aa}$ \\
\hline
\end{tabular}

${ }^{1}$ Means followed by distinct letters, upper case in the row and lowercase in the column, belong to distinct groups, by the Scott-Knott test at 0.05 of significance.

The micronaire index is related to the external diameter of the fiber, observing that ate the sowing season performed at 13/01/17, despite presenting the lower temperatures, favored the expression of the characteristic. However, Rosolem and Echer (2015) warn that the main limiting factor for late sowing is the occurrence of low nocturnal temperatures, which can lead to the production of short fibers, with high disuniformity and low micronaire.

The sowing season 1 provided higher fiber maturity values, since it was the best environment for temperature and precipitation conditions (Table $3)$. The fiber maturity consists of secondary wall thickness formed by the deposition of successive layers of cellulose during its development, derived from photoassimilates, being mainly dependent on environmental conditions such as water availability and adequate handling throughout the crop (DAVIDONIS et al. 2004).
The fiber length characteristic (UHML) is classified as long for values between 27 and $32 \mathrm{~mm}$ and very long above $32 \mathrm{~mm}$ (EMBRAPA, 2002) (Table 5). All genotypes presented values of fiber length (UHML) greater than $28 \mathrm{~mm}$, being classified as long fiber, independent of the growing seasons. Although not statistically different, genotypes DP-555, FM-966, UFUJP-C and UFUJP$\mathrm{Z}$ obtained the highest averages for the characteristic in question. 
Table 5. Length and uniformity of fiber length of cotton genotypes as a function of sowing seasons. Uberlândia, Minas Gerais State, Brazil, 2016/2017.

\begin{tabular}{ccccccccc}
\hline \multirow{2}{*}{ Genotype } & \multicolumn{7}{c}{ Sowing season } \\
\cline { 2 - 9 } & \multicolumn{2}{c}{$05 / 12 / 16$} & \multicolumn{2}{c}{$19 / 12 / 16$} & \multicolumn{2}{c}{$30 / 12 / 16$} & \multicolumn{2}{c}{$13 / 01 / 17$} \\
\cline { 2 - 8 } & UHML & UI & UHML & UI & UHML & UI & UHML & UI \\
\hline DP-555 & 30.90 & 83.50 & 30.70 & 82.25 & 30.63 & 82.67 & 29.96 & 81.87 \\
FM-966 & 30.61 & 82.90 & 30.82 & 82.35 & 29.95 & 81.72 & 29.91 & 83.12 \\
UFUJP-A & 28.56 & 82.52 & 30.46 & 82.52 & 30.25 & 83.50 & 29.78 & 83.32 \\
UFUJP-C & 30.66 & 83.97 & 30.44 & 84.37 & 31.05 & 84.97 & 30.13 & 83.42 \\
UFUJP-P & 30.49 & 83.70 & 29.74 & 84.92 & 29.67 & 83.75 & 29.60 & 81.35 \\
UFUJP-S & 30.45 & 82.75 & 28.90 & 83.10 & 29.73 & 83.30 & 29.93 & 82.57 \\
UFUJP-Z & 30.99 & 82.95 & 30.57 & 83.15 & 29.67 & 82.82 & 30.04 & 83.40 \\
Average & $30.39 \mathrm{~A}$ & $83.19 \mathrm{~A}$ & $30.24 \mathrm{~A}$ & $83.22 \mathrm{~A}$ & $30.14 \mathrm{~A}$ & $83.25 \mathrm{~A}$ & $29.91 \mathrm{~A}$ & $82.73 \mathrm{~A}$ \\
\hline
\end{tabular}

Means followed by distinct letters, uppercase in the row belong to distinct groups, by the Scott-Knott test at 0.05 of significance.

Only the fiber length does not differ statistically, a tendency of length decrease with later seasons is generally observed. This fact agrees with the work of Gipson and Johan (1968) who verified that the maximum fiber length decreases when the nocturnal temperatures are not lower than $15^{\circ} \mathrm{C}$, a fact that occurred in seasons 3 and 4 of this experiment.

For the characteristic uniformity of length (UI), the environments did not differ from each other. The genotypes showed UI above $81 \%$ in all seasons, being classified as uniform (Table 5), therefore, it is little influenced by the environment, with values differing found among genotypes stemming from their own genetic makeup.

According to Table 6, the fibers were classified with low (6 to $9 \mathrm{~mm}$ ) and very low (less than $6 \mathrm{~mm}$ ) short fibers index (EMBRAPA, 2002), as well as scored by Silva et al. (2013) and Bonifácio et al. (2015), high short fiber index (SF) values are undesirable, once many mendings would be necessary during spinning, impairing the quality of the final product. This characteristic is very influenced by the harvest and the ginning, being uniform between the seasons and the genotypes.

Sowing seasons interfered significantly for the elogation characteristic (ELG). The genotypes FM-966, UFUJP-A, UFUJP-C and UFUJP-Z obtained high values, between 7.17 and $7.46 \%$ (Table 5) (EMPRAPA, 2002). Similar results were found by Violatti (2016) when studying fiber quality and genetic diversity in white fiber cotton. The best sowing season for elongation characteristic was season $2(19 / 12 / 2016)$.

Fiber elongation is a characteristic strongly influenced by the availability of water during flowering and its development in the first 20 days after anthesis (ECHER, 2014). In season 1 there was a significant reduction of rainfall in flowering, a fact that did not occur in season 2, which obtained average rainfall of over $15 \mathrm{~mm}$ per day ${ }^{-1}$.

For fiber resistance (STR) the sowing seasons did not differentiate between them and the genotypes DP-555, UFUJP-A, UFUJP-C and UFUJP-S were classified with very high resistance (above 31 gf tex-1), presenting as promising genotypes for breeding, targeting textile industry standards (Table 5).

For resistance, the most critical interval to obtain better resistance occurs in the final period of fruit formation, with the formation of the secondary walls of the fibers, constituted mainly by cellulose (YEATES et al., 2010). However, Echer (2014) in a survey on abiotic stress in cotton reported that there was no consensus in the scientific literature regarding the influence of temperature on fiber resistance.

It is necessary to simultaneously analyze the agronomic results and fiber quality characteristics of this work. It was observed that, in general, the influence of the sowing season was higher for productivity and less for the technological characteristics of the fiber. In addition, a later planting $(01 / 13 / 17)$ would not be recommended for the region of Uberlândia, due to lower yields, maturity and elongation of the fiber caused by the scarcity of rain in the boll filling, associated with lower temperatures (lower than $15^{\circ} \mathrm{C}$ ), delaying its development, which results in the killing of the reproductive structures, besides a higher incidence of plagues such as the cotton boll weevil (Anthonomus grandis) (MAPA, 2017). 


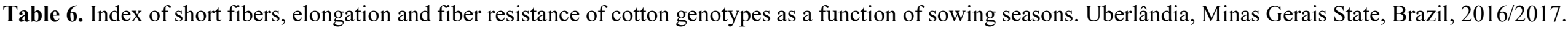

\begin{tabular}{|c|c|c|c|c|c|c|c|c|c|c|c|c|c|c|c|}
\hline \multirow{3}{*}{ Genotype } & \multicolumn{12}{|c|}{ Sowing season } & \multirow{2}{*}{\multicolumn{3}{|c|}{ Mean }} \\
\hline & \multicolumn{3}{|c|}{$05 / 12 / 2016$} & \multicolumn{3}{|c|}{$19 / 12 / 2016$} & \multicolumn{3}{|c|}{$30 / 12 / 2016$} & \multicolumn{3}{|c|}{ 13/01/2017 } & & & \\
\hline & SFI & ELG & STR & SFI & ELG & STR & SFI & ELG & STR & SFI & ELG & STR & SFI & ELG & STR \\
\hline DP-555 & 6.37 & 6.52 & 31.82 & 7.25 & 7.5 & 29.75 & 6.97 & 7.05 & 30.3 & 7.15 & 6.82 & 30.75 & 6.94 & 6.97 & 30.66 \\
\hline FM-966 & 6.67 & 7.27 & 29.97 & 6.9 & 7.52 & 29.07 & 6.82 & 7.62 & 29.62 & 6.52 & 7.42 & 30.07 & 6.73 & 7.46 & 29.68 \\
\hline UFUJP-A & 6.75 & 7.45 & 31.47 & 7 & 7.25 & 31.65 & 6.07 & 7.55 & 31.97 & 6.72 & 6.97 & 30.47 & 6.64 & 7.31 & 31.39 \\
\hline UFUJP-C & 6.15 & 6.75 & 30.52 & 5.87 & 7.62 & 32.8 & 5.84 & 6.85 & 31.1 & 6.87 & 7.45 & 29.75 & 6.18 & 7.17 & 31.04 \\
\hline UFUJP-P & 6.9 & 6.3 & 31.15 & 5.97 & 7.35 & 30.65 & 6.35 & 6.55 & 30.9 & 7.82 & 7.27 & 28.4 & 6.76 & 6.87 & 30.28 \\
\hline UFUJP-S & 7.62 & 6.87 & 32.25 & 6.72 & 7.3 & 30.97 & 6.85 & 6.72 & 31.15 & 6.2 & 7.02 & 31.7 & 6.85 & 6.98 & 31.52 \\
\hline UFUJP-Z & 6.8 & 6.6 & 31.62 & 6.22 & 7.85 & 28.62 & 7.2 & 7.72 & 28.97 & 6.65 & 7.47 & 29.47 & 6.72 & 7.41 & 29.67 \\
\hline
\end{tabular}

${ }^{1}$ Means followed by distinct letters, uppercase in the row belong to distinct groups, by the Scott-Knott test at 0.05 of significance. 


\section{CONCLUSIONS}

The genotypes presented different performances regarding productivity in relation to sowing seasons. Seeding carried out in the first half of December resulted in higher productivity of cotton, with emphasis on genotype UFUJP-Z. The UFUJP-S genotype proved to be more adapted to the second half of December, even in adverse conditions. For the quality of the fiber, genotype UFUJP-C stood out and the best season was the second sowing season $(12 / 19 / 16)$.

\section{ACKNOWLEDGEMENT}

We acknowledge Coordenação de Aperfeiçoamento de Pessoal de Nível Superior (CAPES) for financial assistance. We are also grateful to Associação Mineira de Produtores de Algodoeiro of Minas Gerais (AMIPA) and to the Programa de Melhoramento Genético de Algodoeiro (PROMALG) for all assistance and support.

RESUMO: O algodão é um dos principais produtos agrícolas produzidos no Brasil. Com tamanha exigência do mercado, é necessário que as cultivares de algodoeiro apresentem alta produtividade e qualidade de fibras. Para favorecer a expressão do potencial dos genótipos, a semeadura deve ocorrer na época em que as condições climáticas proporcionem bom desenvolvimento das plantas, sendo a temperatura, precipitação e luminosidade fatores primordiais para o bom desempenho. Com o intuito de estabelecer uma época de semeadura ideal para diferentes genótipos de algodoeiro, o presente estudo teve como objetivo avaliar a melhor época de semeadura, para o ambiente de Uberlândia (MG), visando produtividade e qualidade da fibra. $\mathrm{O}$ experimento foi desenvolvido em condições de campo, na safra 2016/2017 na área experimental localizada na Fazenda Capim Branco, no município de Uberlândia, Minas Gerais. Utilizou-se delineamento experimental de blocos completos casualizados (DBC) com quatro repetições em esquema fatorial 4x7, constituíram-se de 4 épocas de semeadura: 05/12, 19/12, 30/12, 13/01 e 7 genótipos, sendo 5 linhagens do Programa de melhoramento do algodoeiro da Universidade Federal de Uberlândia (UFU) e 2 cultivares comerciais. As características avaliadas foram: produtividade do algodão em caroço, rendimento de pluma, índice micronaire, índice de maturação, comprimento de fibra, uniformidade de comprimento, fibras curtas, resistência e alongamento. Concluiu-se que a semeadura em 05/12/16 obteve melhores resultados quando visa alta produtividade, com destaque para o genótipo UFUJP-Z. Visando qualidade de fibra a semeadura em 19/12/16 foi mais favorável, com destaque para o UFUJP-C.

PALAVRAS-CHAVE: Condições temporais. Gossypium hirsutum. Micronaire.

\section{REFERENCES}

ALMEIDA, E. S. A. B.; PEREIRA, J. R.; AZEVEDO, C.A.V.; ARAÚJO, W.P.; ZONTA, J.H.; CORDÃO, M.A. Algodoeiro herbáceo submetido a déficit hídrico: Produção. Agropecuária Científica no Semiárido, v.13, n.1, p.22-28, 2017.

AMORIM NETO, M. DA S.; BELTRÃO, N.E. DE M.; MEDEIROS, J. DA C. Indicadores edafo-climáticos para o zoneamento do algodoeiro arbóreo. In: Congresso Brasileiro de Agrometeorologia, 10, 1997, Piracicaba. Anais... Piracicaba: Sociedade Brasileira de Agrometeorologia, 1997. p.369-371.

BELTRÃO, N. E. M.; AZEVEDO, D. M. P. Agronegócio do algodão no Brasil. 2 rev. ampl. Brasília: EMBRAPA, 2008. p. 5.

BELTRÃO, N.E. de M. Caracterização de sistemas e tecnologia de cultivo para a cotonicultura herbácea com ênfase para o Norte de Minas Gerais. Campina Grande: EMBRAPA-CNPA, 1997. 56 p. (EMBRAPACNPA. Documentos, 55).

BELTRÃO, N. E. M.; FIDELES FILHO, J.; VALE, L. S.; FREIRE, E. C. Zoneamento agroclimático do algodoeiro no cerrado brasileiro. In: FREIRE, E. C. Algodão no cerrado do Brasil. Brasília: Gráfica e Editora Positiva, 2015, chapter.2, p. 39-63. 
BONIFÁCIO, D. O. C.; MUNDIM, F. M.; SOUSA, L. B. Variabilidade genética e coeficiente de determinação em genótipos de algodoeiro quanto a qualidade da fibra. Revista Verde, v. 10, n.3, p. 66-71, 2015.

https://doi.org/10.18378/rvads.v10i3.3618

CARVALHO, L. H.; SILVA, N. M., KONDO, J. I., CIA, E., CHIAVEGATTO, E., CARVALHO, H. D. R. Estudo de época de plantio do algodoeiro adensado na região de Campinas-SP. In: CONGRESSO BRASILEIRO DE ALGODÃO, $8^{\circ}$ COTTON EXPO, 2011, São Paulo. Embrapa Algodão-Artigo em anais de congresso (ALICE). Campina Grande, PB: Embrapa Algodão, 2011.

CHITARRA, L.G. Identificação e controle das principais doenças do algodoeiro. 3 ed. Campina Grande: Embrapa Algodão, 2014.

COMPANHIA NACIONAL DE ABASTECIMENTO (Brasil). Acompanhamento da safra brasileira de grãos: v. 11 safra 2017/18 - Décimo primeiro levantamento, Brasília, DF: CONAB, 2018. Available in:< https://www.conab.gov.br/infoagro/safras/graos >. Access in: dez. 222018.

CRUZ, C. D. GENES: a software package for analysis in experimental statistics and quantitative genetics. Acta Scientiarum, Agronomy, v. 35, n. 3, p. 271-276, 2013. https://doi.org/10.4025/actasciagron.v35i3.21251

DAVIDONIS, G. H.; JOHNSON, A. S.; LANDIVAR, J. A.; FERNANDEZ, C. J. Cotton Fiber Quality is Related to Boll Location and Planting Date. Agronomy Journal, v. 96, p. 42-47, 2004.

ttps://doi.org/10.2134/agronj2004.0042

ECHER, F. R. O algodoeiro e os estresses abióticos: temperatura, luz, água e nutrientes. Cuiabá: Instituto Mato-Grossense do Algodão, 2014, 123 p.

EMBRAPA. Sistema brasileiro de classificação de solos. 3. ed. Brasília, DF: Embrapa Solos, 2013. 353 p.

EMBRAPA. Resultados de ensaio HVI e suas interpretações (ASTM D-4605). Campina Grande, 2002. (Circular técnica, 66).

FERREIRA, A. C. B.; BORIN, A. L. D. C.; BRITO, G. G.; SILVA FILHO, J. L.; BOGIANI, J. C. Épocas de semeadura, cultivares e densidades de plantas para algodão adensado em segunda safra. Pesquisa

Agropecuária Tropical, v. 45, n. 4, p. 397-405, 2015. https://doi.org/10.1590/1983-40632015v4536869

FREIRE, E. C. Melhoramento no Brasil. In: BORÉM, A.; FREIRE, E. C. Algodão: do plantio a colheita. Viçosa, MG: UFV, 2014. cap.6, p. 113-155.

LACA-BUENDÍA, J. P. et al. Avaliação de Épocas de Plantio para Genótipos Precoces de Algodoeiro Herbáceo no Município de Uberaba - MG. FAZU em Revista, Uberaba, n.2, p. 3-10, 2005

MAHMOOD-UL-HASSAN, M. N.; MUHAMMAD ZAFFARIQBAL, T. M.; MUHAMMAD, I.; SAGHIR, A. Effect of Different Sowing Dates on Cotton (Gossypium hirsutum L.) Cultivars. Asian Journal of Plant Sciences, v. 2, n. 6, p. 461-463, 2003. https://doi.org/10.3923/ajps.2003.461.463

MIRANDA, M. C. C. Diversidade genética entre genótipos de algodoeiro visando ampliação da variabilidade. 2019, 67 f. Dissertação (Mestrado) - Curso de Pós-Graduação em Agronomia, Universidade Federal de Uberlândia, Uberlândia, 2019.

PENNA, J. C. V. Melhoramento do algodão. In: BORÉM, A. Melhoramento de espécies cultivadas. 2. ed. Viçosa, MG: UFV, 2005. chapter.1, p. 15-53. 
RIBEIRO. A. C.; GUIMARÃES, P. T. G.; ALVARES V.; V. H. Recomendações para o uso de corretivos e fertilizantes em Minas Gerais: $5^{\text {a }}$ Aproximação. Viçosa, MG: Comissão de Fertilidade do Solo do Estado de Minas Gerais, 1999.

ROSOLEM, C. A.; KAWAKAMI, E. M.; CHIAVEGATO, E. J.; ECHER, R. F.; BRITO, G. G.; CARVALHO, H. DA R.; SNIDER, J. L.; BOGIANI, J. C.; BERNARDES, M. S.; YEATES, S. O algodoeiro e os estresses abióticos: temperatura, luz, água e nutrientes. Embrapa Agropecuária Oeste-Outras publicações científicas (ALICE). Cuiabá/MT, p. 13-25, 2014.

ROSOLEM, C. A.; ECHER, F. R. Ecofisiologia do Algodoeiro: Implicações na Época de Semeadura e Qualidade. In: FREIRE, E. C. Algodão no cerrado do Brasil. Brasília, DF: Gráfica e Editora Positiva, 2015. chapter.14, p. 533-558.

ROSOLEM, C.A. Exigências Edafoclimáticas. In: BOREM, A.; FREIRE, E.C. Algodão: do plantio a colheita. Viçosa, MG: UFV, 2014. chapter. 4. p. 67-87.

SCOTT, A. J.; KNOTT, M. A cluster analysis method for grouping means in the analysis of variance.

Biometrics, v. 30, n. 3, p. 507-512, 1974. https://doi.org/10.2307/2529204

SILVA, G.; OLIVEIRA, R. A.; QUEIROZ, N. L. Q.; MELCHIOR N. B. SILVA, M. F. S. S. Desempenho agronômico de algodão orgânico e oleaginosas consorciados com palma forrageira. Engenharia agrícola e ambiental, v.17, p.975-981, 2013. https://doi.org/10.1590/S1415-43662013000900010

VIOLATTI, M. R. Qualidade da Fibra e Diversidade Genética em Algodoeiro de Fibra Branca. 2016, 44 f. Dissertação (Mestrado) - Curso de Pós-Graduação em Agronomia, Universidade Federal de Uberlândia, Uberlândia, MG, 2016. 